\title{
Printed Marginalia, Extractive Reading, and Josuah Sylvester's Devine Weekes (1605)
}

\author{
PETER AUGER \\ Queen Mary University of London
}

Guillaume de Saluste Du Bartas's Semaines (first published 1578, 1584, et seq.) were among the most widely read, translated, and reprinted vernacular poems in early modern Europe. By 1623 there were at least forty-two French editions of La sepmaine (1578), a creation epic in alexandrines that describes each day of the first week with extensive catalogs, informed by classical and Renaissance sources, describing the earth's formation and population. ${ }^{1}$ La seconde semaine (1584 et seq.), of which at least twenty-nine French editions were printed by 1623, takes the biblical-historical narrative from the book of Genesis forward: the four days that Du Bartas completed, each divided into four parts, recount the eras of Adam (II.i), Noah (II.ii), Abraham (II.iii), and David (II.iv). ${ }^{2}$ The poems were equally popular outside France: there were sixteenth- or seventeenth-century translations into Latin (by four separate translators between 1579 and 1609), Italian (reprinted five times between 1592 and 1613), Dutch (by at least four separate translators in the early 1600s), Spanish (1610 and, in prose, 1612), German (1619 et seq.), Danish (1661), and Swedish (1685). ${ }^{3}$

I gratefully acknowledge that this research was supported by the Arts and Humanities Research Council. I thank Gavin Alexander, Giles Bergel, and other readers (including the anonymous readers for Modern Philology) for their helpful comments on earlier versions of this article.

1. Urban Tigner Holmes Jr., John Coriden Lyons, Robert White Linker, et al., eds., The Works of Guillaume de Salluste, Sieur Du Bartas, 3 vols. (Chapel Hill: University of North Carolina Press, 1935-40), 1:70-83; Yvonne Bellenger, Du Bartas et ses divines semaines (Paris: SEDES, 1993), 155, 165; Yvonne Bellenger, ed., La sepmaine: Texte du 1581 (Paris: Nizet, 1981), lvi-lx.

2. Holmes et al., Works, 1:84-97; Yvonne Bellenger, ed., La seconde semaine (1584), 2 vols. (Paris: Société des Textes Français Modernes, 1991), 1:xx-xxiii. In the parenthetical citations to this work, capital Roman numerals refer to "Week" of the poem, and the lowercase Roman numerals refer to "Day."

3. Yvonne Bellenger and Jean-Claude Ternaux, Bibliographie des ecrivains français: Du Bartas (Paris: Memini, 1998), 29-36.

(C) 2015 by The University of Chicago. All rights reserved. 0026-8232/2015/11301-0004\$10.00 
Eight contemporary translators rendered single Days or whole Weeks of the Semaines into English: James VI and I (1591), Philip Sidney (ca. 1586; the translation is lost), an anonymous translator possibly linked to John Hoskyns and the Middle Temple (1595), William Lisle (1596 et seq.), Thomas Winter (1603, 1604), William Scott (ca. 1600), Robert Barret (ca. 1602), and Josuah Sylvester, whose first translation from Du Bartas was printed in 1590 and who went on to translate the whole Semaines, first published as Devine Weekes and Workes in $1605 .{ }^{4}$ Susan Snyder, editor of Sylvester's translation, claimed with due cause that "everyone in pre-Restoration England who had received a literary education read the Weekes and almost all ... admired it." ${ }^{5}$

Du Bartas's name is much less widely known today, even though French scholars in the 1980s, particularly James Dauphiné and Yvonne Bellenger, worked to recover the scientific, bibliographical, generic, and theological contexts vital for appreciating the early significance of the Semaines. ${ }^{6}$ Among scholars of English literature, Du Bartas is probably best known through mediating allusions such as Edmund Spenser's praise in the envoi of Ruines of Rome (1591), John Milton's invocation to the Christian muse Urania in book 7 of Paradise Lost (1667, a poem for which Du Bartas's epic scope and biblical subject matter may have served as a model), and other references made by contemporary poets like Anne Bradstreet and Andrew Marvell. ${ }^{7}$ Du Bartas's profile and reputation remain low. Robert Cummings is only upholding the earlier skepticism of critics such as Douglas Bush, who called the Semaines "a kind of Albert Memorial of encyclopaedic fundamentalism," when Cummings argued recently that the poems were more attractive for

4. See The Divine Weeks and Works of Guillaume de Saluste, Sieur du Bartas, trans. Josuah Sylvester, ed. Susan Snyder (Oxford: Clarendon, 1979), 70-71. See below for Scott's translation; the putative Hoskyns link is based on the initials "Io. Ho." found on Alr of The First Day (1595), Short Title Catalogue [STC] 21658. The STC is available online at http://estc.bl.uk. Hereafter, STC numbers will appear parenthetically in the text following the publication date of the work cited. For such items, place of publication is London unless otherwise noted.

5. Oxford Dictionary of National Biography, s.v. "Sylvester, Josuah [Joshua] (1562/3-1618), poet and translator," by Susan Snyder, http://www.oxforddnb.com/view/article/26873. See also Anne Lake Prescott, French Poets and the English Renaissance: Studies in Fame and Transformation (New Haven, CT: Yale University Press, 1978), 167-234; and Peter Auger, "The Semaines' Dissemination in England and Scotland until 1641," Renaissance Studies 26 (2012): 625-40.

6. Yvonne Bellenger, "État present des études sur Du Bartas en France depuis 1970," Oeuvres et Critiques 29 (2004): 9-26.

7. See esp. George Coffin Taylor, Milton's Use of Du Bartas (Cambridge, MA: Harvard University Press, 1934); Richard Danson Brown, The New Poet: Novelty and Tradition in Spenser's Complaints (Liverpool University Press, 1999), 157-58; The Works of Anne Bradstreet, ed. Jeannine Hensley (1967; repr., Cambridge, MA: Harvard University Press, 2005), e.g., 14, 192-95; and Ian C. Parker's articles in Notes and Queries, e.g., "Marvell and the 'Tygress fell,'” Notes and Queries 52 (2005): 318-24. 
their epigrammatic character than as religious or philosophical epics and that "the architecture of the Divine Weeks amounts to improvisatory construction on a rickety frame."

While accepting that Du Bartas's works will never be esteemed as highly as they were between about 1580 and 1660, critics can nonetheless learn much about the aesthetic and practical value of early modern poetry from the abundant early texts of the Semaines and the equally abundant contemporary responses to them. This article seeks to reduce the historical distance between earlier and later readings of Du Bartas's epic poetry by showing how early responses to these poems were contingent on the material forms in which they were read, an approach that Anne Lake Prescott was the first to advocate and that is well supported by recent work in bibliography, book history, and the history of reading. ${ }^{9}$ Why were the Semaines printed so often? How did page layout vary between different editions and translations? What can the printed page tell us about the expectations and ideas that readers brought to these poems? How did readers use their copies, and how should we?

This article concentrates on the extensive printed marginalia that are found in most early modern texts of the Semaines but none of the critical editions available today-in particular the marginalia that were originally composed by the Huguenot scholar Simon Goulart and that appear, translated, in all seventeenth-century editions of Sylvester's Devine Weekes. The first section of this article explores the intellectual, cultural, and biblical contexts within which marginalia were produced and used in editions of Du Bartas before Sylvester's Devine Weekes was printed in 1605. Early publishers and printers appear to have been much more willing to tolerate the additional labor and paper costs required to include marginalia than were their twentieth-century successors. The annotations were apologetically omitted from the Chapel Hill edition of Du Bartas's works in the 1930s: "We have separated the poems from his [Goulart's] famous commentary in this edition; time and money would not have permitted otherwise. ${ }^{.10}$ Simi-

8. Douglas Bush, English Literature in the Earlier Seventeenth Century: 1600-1660 (Oxford: Clarendon, 1962), 73; Robert Cummings, "Reading Du Bartas," in Tudor Translation, ed. Fred Schurink (Basingstoke: Palgrave Macmillan, 2011), 180. Cummings summarizes anglophone criticism on Du Bartas in English in "Recent Studies in English Translation, c. 1590-c. 1660: Part 2: Translations from Vernacular Languages," English Literary Renaissance 39 (2009): 591-92.

9. Anne Lake Prescott, "Du Bartas and Renaissance Britain: An Update," Oeuvres et Critiques 29 (2004): 27, 33; and, e.g., Jennifer Richards and Fred Schurink, "Introduction: The Textuality and Materiality of Reading in Early Modern England," Huntington Library Quarterly 73 (2010): 345-61; Paul Eggert, "Brought to Book: Bibliography, Book History and the Study of Literature," Library 13 (2012): 3-32, and "The Way of All Text: The Materialist Shakespeare," in Voice, Text, Hypertext: Emerging Practices in Textual Studies, ed. Raimonda Modiano, Leroy F. Searle, and Peter Shillingsburg (Seattle: University of Washington Press, 2004), 162-76.

10. Holmes et al., Works, 1:25. 
larly, the texts prepared by Yvonne Bellenger in the 1980s do not reprint notes alongside the poems, though her text of the Suittes to La seconde semaine does adopt the "solution bâtarde" (hybrid solution) of providing Goulart's annotations as footnotes. ${ }^{11}$

In later editions of Devine Weekes, only Alexander Grosart's unreliable 1880 text of Sylvester's complete works imports marginalia from the 1641 folio edition. ${ }^{12}$ When reviewing the Oxford Clarendon edition of Sylvester's translation, Prescott was alert to the interpretative clues that the marginalia might have supplied: "Some readers might enjoy seeing the original marginal glosses. Professor Snyder quotes them occasionally in her notes, but to have them on the page next to the lines they were meant to illuminate would offer further insights into older assumptions and attitudes." ${ }^{\text {"3 }}$ Snyder had defended their omission on the grounds that "the glosses provide little more than a running outline of the work." ${ }^{4}$ Their absence was consistent with an editorial policy that sought to deliver "a text that reproduces as closely as possible the translator's intentions" and gave precedence to earlier, unannotated editions that lack "the corruptions of later reprints." The second section of this article looks closely at the marginalia in Sylvester's influential translation, asking why they appeared for the first time in Devine Weekes (1605), what role the printer Humfrey Lownes is likely to have played in their composition, and what marginalia can tell us about how printer and translator envisaged their book being read.

The final section of the article turns from expected to actual use of Devine Weekes, drawing on evidence of reading practices from print and manuscript materials. Such sources are inevitably weighted toward active readers, especially those who sought to excerpt and recycle material from the text. Though extractive reading may not be representative of contemporary responses as a whole, these encounters nonetheless provide valuable examples of how marginalia reflected and affected book use. In doing so they broaden our appreciation of the spectrum of ways that these poems were first read. These examples also allow us to judge how far the absence of marginalia from modern editions illustrates the distance between modern and early modern evaluations of Du Bartas, and has perhaps even contributed to the continued neglect of these major early modern poems.

11. Yvonne Bellenger, ed., Les suittes de la seconde semaine (Paris: Société des Textes Français Modernes, 1994), xxviii.

12. Josuah Sylvester, Complete Works, ed. Alexander B. Grosart, 2 vols. (1880; repr., Hildesheim: Georg Olms Verlagsbuchhandlung, 1969).

13. Anne Lake Prescott, review of The Divine Weeks and Works of Guillaume de Saluste, Sieur du Bartas, ed. Susan Snyder, Renaissance Quarterly 33 (1980): 460-62.

14. Snyder, Divine Weeks, viii.

15. Ibid., 106; see also vii. 
A letter written in 1584 from Simon Goulart to Joseph Justus Scaliger confirms that Du Bartas knew about and may have authorized Goulart's massive undertaking to produce a commentary and accompanying marginalia for the Semaines. ${ }^{16}$ Although Pantaleon Thevenin also wrote a commentary for La sepmaine in 1584, and Claude Duret compiled one for La seconde semaine, neither was as widely used as Goulart's edition was in France and across Europe. ${ }^{17}$ The fruits of Goulart's labors appeared in the edition of La sepmaine printed by Jacques Chouët in 1581, and the same printer's edition of La seconde semaine in 1589; in all, thirty editions containing the annotations were printed before $1628 .{ }^{18}$ Goulart was a reformed minister and protégé of Theodore Beza in Geneva, whose literary career was largely directed toward translating and otherwise popularizing theological and other humanist writings. ${ }^{19}$ In a period when it was more common to produce annotated editions of classical verse and philosophical or theological prose, Goulart's descriptive commentary on these vernacular poems indicated his high regard for their aesthetic and moral value and brought them prestige as well as a wider readership. ${ }^{20}$

The marginalia employed the same humanist methods of commonplacing, glossing, annotation, and extraction used to read and analyze classical verse. Ann Moss writes:

By the 1570s it was more or less the norm for editions of classical poets to be printed with marginal indications of passages exemplifying commonplaces, rhetorical figures, and places of dialectical argumentation. Such editions were geared to methods of classroom teaching so general as to guarantee sales and reprints and widespread familiarity. The former pupils of those classrooms transferred the reading habits imprinted on them to vernacular literary texts, and publishers of those texts supplied the necessary marginal adjuncts. Thus, material presentation could help to align vernacular texts with the classical canon and eventually ensure that they were read and used like other works in that canon. $^{21}$

In this way the earliest readers of the Semaines were encouraged to adapt methods of dialectical analysis ingrained from their reading of Greek and

16. Leonard Chester Jones, Simon Goulart, 1543-1628 (Geneva: Georg, 1917), 373.

17. Bellenger, Sepmaine, lx, lxii-lxiii, and Seconde semaine, $1: x v$, xvi, xlvii.

18. Jones, Simon Goulart, 576-82.

19. T. de Morembert, "Simon Goulart," in Dictionnaire de biographie francaise, 22 vols. to date (Paris: Letouzey et Ané, 1933-), 16:737-38; Jones, Simon Goulart, 285.

20. Cécile Huchard, D'encre et de sang (Paris: Honoré Champion Éditeur, 2007), 106.

21. Ann Moss, Printed Commonplace Books and the Structuring of Renaissance Thought (Oxford: Clarendon, 1996), 210. 
Latin poets. This was not to impose a foreign interpretative system on the Semaines; as Jan Miernowski has comprehensively demonstrated, such dialectical and epistemological structures were essential to the poems' composition. ${ }^{22}$ Readers who followed these methods would break down these vast poems into their constituent topics and extract pregnant phrases for possible reuse. Marginalia assisted in these tasks by slicing the text into smaller units, summarizing the content of verse paragraphs, demonstrating the work's organizational scheme, and clarifying difficult terms and esoteric allusions. Goulart warned that marginalia could allow readers merely to "cull out" (in Thomas Lodge's translation of the commentary) attractive phrases, rather than meditate on the poems' "wholsome and necessary fruits": "For they who onely ouer-read Bartas for their delight [sic] sake, or to cull out some Words and Elegancies which please them most, resemble him who would plow vp and manure a rich plat of ground, to the end only he might gather flowers to be garlands, \& Nosegayes of little countenance, respectlesse of such wholsome and necessary fruits, as are more commodious for mans life, and whereof he might better make very good prouision." ${ }^{23}$ In facilitating the easy retrieval of striking passages on specific topics such as drought, fruit trees, or vipers, marginalia encouraged the poems to be approached as texts that were potentially useful for readers' own writing and thinking, and some readers indeed did take a rigorously utilitarian approach to them (as is shown below). ${ }^{24}$

Such habits of discontinuous reading were arguably implicit within the poems' design and theology. Contemporary readers often cited the simile in La sepmaine likening the world to a book: "The World's a Booke in Folio, printed all / With God's great Workes in Letters Capitall: / Each Creature, is a Page, and each effect, / A faire Caracter, void of all defect" (I.i.173-76). The poems, like the natural world they described, were replete with an array of signs and phenomena that testified to their Creator's informing presence and could only ever be experienced serially and partially. Violaine Giacomotto-Charra, like other francophone critics, argues that Du Bartas's poetic structures are self-consciously limited and that his poetic descriptions are intimately aligned with Calvinist biblical exegesis: "To avoid all allegorical readings, La sepmaine practices descriptive and scientific reading: the

22. Jan Miernowski, Dialectique et connaissance dans "La sepmaine" de Du Bartas: "Discours sur discours infiniment divers" (Geneva: Droz, 1992).

23. Simon Goulart, A Learned Summary upon the Famous Poeme (the first and second Weeke) of William of Saluste lord of Bartas, trans. Thomas Lodge (London, 1621, STC 21666; repr., 1637, STC 21667, and 1638, STC 21668), *4r.

24. Ann Blair, Too Much to Know: Managing Scholarly Information before the Modern Age (New Haven, CT: Yale University Press, 2010), esp. chaps. 2-3, and "Reading Strategies for Coping with Information Overload, ca. 1550-1700," Journal of the History of Ideas 64 (2003): 11-28. 
poem opts to evoke empirical objects where Calvin's commentary is lexical and theological." 25 As well as describing real flora and fauna, the Semaines are sown with rhetorical flowers that are organized under a set of general headings grounded on scriptural authority and divided into heroic couplets to make them easier to pick out.

Biblical annotation was a specific precedent for the marginalia in Du Bartas's scriptural poetry. Printed marginalia featured prominently and controversially in the Geneva Bible, and also in the Authorized (King James) Version, the translators of which defended their inclusion by arguing that notes make readers more alert: "Doth not a margin do well to admonish the Reader to seek further, and not to conclude or dogmatize upon this or that peremptorily?" 26 As Evelyn Tribble observes, biblical marginalia "organiz[ed] the experience of the reader" and directed exegetical attention. ${ }^{27}$ Printed Bibles used during the Christian liturgical year continued to privilege nonsequential reading, even after the Reformation. Peter Stallybrass finds that "the use of book-marking systems to index discontinuous passages was, and is, central to the Catholic liturgy" and that Protestant innovations had limited impact in making continuous reading the new liturgical norm: "in examining the Church of England's attempt to produce an 'orderly' (i.e., sequential) reading of the bible, the crucial point remains that there were innumerable exceptions." ${ }^{28}$ Like the book of Genesis, the Semaines could be read as a gathering of archetypal stories as well as a single narrative to be read in sequence. This dichotomy between "Catholic" nonsequentiality and "Protestant" continuity when reading is close to the critical opposition between readings that treat the Semaines as a medieval encyclopedia entire in itself and others that approach the poems as a narrative work that became a predecessor to Milton's Paradise Lost. Though marginalia did not necessarily prioritize or enable one kind of book use only, clearly the Semaines did lend themselves to extraction and reading in parts, and printed annotations supported such practices. Both in early modern Bibles and vernacular poems like the Semaines, other finding devices such as tables

25. "Pour éviter toute lecture allégorique, La sepmaine pratique une lecture descriptive et scientifique: elle choisit l'ordre de l'évocation du sensible, là où le commentaire de Calvin est lexical et théologique" (Violaine Giacomotto-Charra, La forme des choses: Poésie et savoirs dans "La sepmaine" de Du Bartas [Toulouse: Presses universitaires du Mirail, 2009], 84), translation mine.

26. "The Translators to the Readers," in The Holy Bible (London, 1611), B2r. See also William W. E. Slights, Managing Readers: Printed Marginalia in English Renaissance Books (Ann Arbor: University of Michigan Press, 2001), 118 n. 33.

27. Evelyn B. Tribble, Margins and Marginality: The Printed Page in Early Modern England (Charlottesville: University Press of Virginia, 1993), 43.

28. Peter Stallybrass, "Books and Scrolls: Navigating the Bible," in Books and Readers in Early Modern England: Material Studies, ed. Jennifer Lotte Andersen and Elizabeth Sauer (Philadelphia: University of Pennsylvania Press, 2002), 47, 50. 
of contents, running headers, indexes, increasingly consistent pagination, and cross-references complemented marginalia and facilitated diverse reading strategies. ${ }^{29}$

English translations of the Semaines made before the publication of Devine Weekes were responsive to these intellectual, pedagogical, and theological contexts. The whole commentary was available in Thomas Lodge's English translation, which was printed separately from the poems in 1621, 1637, and 1638, and annotations are found in most early editions printed in London other than Sylvester's. ${ }^{30}$ The Anglo-Saxon scholar William Lisle's translation of "Babilon" (II.ii.2) advertised on the title page that it contained the "Commentarie, and marginall Notes of S. G. S. [Simon Goulart de Senlis]," and in his translation of "Les colonies" (II.ii.3) Lisle claims to have "in diuerse places corrected and enlarged" upon Goulart's work. ${ }^{31}$ Lisle's expanded editions published in 1625 and 1637 also contain notes and commentary. ${ }^{32} \mathrm{As}$ in the original French editions, the poems are broken up on the page into separate sections divided by Goulart's commentary. Superscript numerals allow the reader to navigate efficiently between text and commentary (which are printed in different types) and often appear at the beginning of verse paragraphs alongside explanatory marginalia. By breaking up the text in this way and providing prose arguments, the poems' informational uses were emphasized on the page. Annotations serve a different function in the anonymous 1595 translation of "Le premier jour." They are original to this edition and occur just once or twice per page on average to clarify the poem's argument and structure (e.g., "The poets inuocation on God"; "A pluralitie of worlds confuted"), provide scriptural references ("Genes.1.2"), and cite relevant Latin maxims ("Sat cito, si sat bene. / Festina lente" [Quick enough, if good enough. Hasten slowly]). ${ }^{33}$ Such marginalia serve as a commentary to the poem but also provide a rough guide to the topics addressed and allow the reader to locate particular arguments, such as "God tooke no view of any externall patterne to make the world after," and "Why God ordained the night to succeed the day." 34 While this

29. On the relationship between paratextual features and reading practices more broadly, see Helen Smith and Louise Wilson, eds., Renaissance Paratexts (Cambridge University Press, 2011).

30. Goulart, Learned Summary.

31. Babilon, a Part of the Second Week (London, 1595, STC 21662), title page; The Colonies of Bartas (London, 1598, STC 21670), title page.

32. Part of Du Bartas, English and French (London, 1625, STC 21663); Four Bookes of Du Bartas (London, 1637, STC 21663a.5).

33. The First Day of the Worlds Creation (London, 1595, STC 21658), A4r, C4v, C4r, D3v, translation mine.

34. Ibid., C1r, E1r. 
publication is short enough to be read board to board in a single sitting, the marginalia again hint at alternative reading strategies.

The marginalia in Thomas Winter's translations from La sepmaine were also composed specially for his publication. His Second Day (1603) glosses individual words marked with an asterisk in the text (e.g., "Cancer" beside "Crabbed hoste"), marks "similes" and "examples," and identifies the poem's skeletal argument (e.g., "Diuerse effects of the hote exhalations"). ${ }^{35}$ Winter's annotations are distinctively scholarly, especially in his translation of "Le troisiesme jour" (1604), which includes detailed cross-references (e.g., "Diosc[orides]. lib. 5. ca. 94") and a thorough outline in the margins, with each verse paragraph accompanied by a heading in the margins and subtopics often specified below, as in the annotation "A continuation of the former argument, confirmed by ocular witnesses of later ages." 36 In addition, marginalia amplify the text's content with additional factual details. On signatures D4v-E1r, for example, the margins are filled with supplementary information and references in Latin and English about the plants and herbs named in the main text: "The Italians (saith Matthiolus) call this herbe [i.e., Lunarie] Sferra-cauallo, that is, Vnshoe horse. Florio seemes to make it all one with the herbe AEthiopis mentioned by Plinie lib. 26. cap. 4" (D4v). In all three of these English editions, marginalia activate new interpretative possibilities, accompany readers working through or across the text, and allow them to pinpoint particular sections and extract their meaning more quickly, with additional assistance provided by summary prose arguments.

Early manuscript translations of the Semaines into English raise different but no less relevant considerations about marginalia and their uses. Robert Barret's and William Scott's translations, which survive in manuscript only, also contain detailed marginal annotation. Their notes are not necessarily identical in function to printed marginalia, which we have seen were part of specific systems of textual organization and interpretation; nor, however, were they just informal scribblings that recorded personal reflections (as we sometimes find in manuscript annotations to printed texts of the Semaines). Still less should we assume that printed marginalia held priority or authority over their manuscript equivalents.

The soldier-poet Robert Barret's translations from La seconde semaine contain, in Prescott's words, frequent "marginal notes identifying rhetorical usage, explaining an obscurity, or outlining the author's meaning," all of which draw attention to textual features that Barret wished to emphasize. ${ }^{37}$ Around half of Barret's marginalia label rhetorical terms, possibly following

35. The Second Day of the First Week (London, 1603, STC 21659), C4v, D3v.

36. The Third Dayes Creation (London, 1604, STC 21660), E4r, C3r.

37. Anne Lake Prescott, "An Unknown Translation of Du Bartas," Renaissance News 19 (1966): 12 . 
Henry Peacham's Garden of Eloquence (1593), given the appearance of rare terms like "Hyrmos" and "Schesis onomaton" together in "The Furies" alongside other terms like "hypozeugma," "apocope," and "ecphonesis." 38 Barret also glosses proper nouns (e.g., "Ophtalmia, a hot imposition in the eies" [46]), reviews the argument (e.g., "Since Mans transgression the secret hatreds of sundry creatures" [40]), and gives brief notes for unfamiliar or obscure terms (e.g., "the Amerik, is the poxe"; "Crauros, the kings Euill" and "Epilepsia, falling sicknes" [51]). Though the annotations may have provided assistance for Barret in composing and navigating his own manuscript, they were probably composed for other potential readers too. Indeed, Barret plausibly had the layout of a printed page in mind when composing his manuscript marginalia. His translation of "The workes of (in parte)" Du Bartas, which contained a "large indexe or comment in order of Alphabett for the vnderstandinge of the hard wordes etc.," was entered into the Stationers' Register to Adam Islip in May 1605, before being struck out with Islip's and Humfrey Lownes's consent. ${ }^{39}$

William Scott's recently discovered manuscript translation of the first two Days of La sepmaine, bound with his treatise The Model of Poesy, contains marginalia throughout as well, some of which paraphrase Goulart's annotations. ${ }^{40}$ These marginalia are consistent with Scott's emphasis in the treatise on Du Bartas as a divine and philosophical poet. They provide pithy summaries of Du Bartas's argument (e.g., "Resurrection" and "transition") that highlight the poem's learning and divide the text into its constituent topics. The frequent use of the word "reason" in marginal notes that are departures from Goulart may correspond to Scott's understanding, described in the treatise, of how Renaissance dialectic informed poetic analysis. ${ }^{41}$ These manuscript examples suggest that marginalia were deemed equally appropriate to the mise-en-page of all translations and that they did not serve a narrowly pragmatic function. Marginalia encouraged a set of approaches and procedures that were not restricted to either print or manuscript. In order to understand more about how the intellectual traditions embodied

38. Garden of Eloquence (London, 1593), H1r, G4v, K2v, C2r, K4r; Barret, "Translations from La seconde semaine," Folger Library, MS V.b.224, 54, 53, 39, 43; future page references are given in parentheses. On vernacular and Latin rhetorical treatises with which writers like Peacham (and perhaps Barret too) were familiar, see the facsimile reproduction edited by William G. Crane (Gainesville, FL: Scholars' Facsimiles \& Reprints, 1954), 9; and, more generally, Peter Mack, A History of Renaissance Rhetoric, 1380-1620 (Oxford University Press, 2011), esp. 300.

39. A Transcript of the Company of Stationers of London, 1554-1640 A.D., ed. Edward Arber, 5 vols. (London, 1875-91), 3:221-22.

40. British Library, MS Add. 81083. See Stanley Wells, "A New Early Reader of Shakespeare," in Shakespeare's Book: Essays in Reading, Writing and Reception, ed. Richard Meek, Jane Rickard, and Richard Wilson (Manchester University Press, 2008), 235.

41. I thank Michael Hetherington for raising this point with me. 
in these early English translations may have affected how the Semaines were appreciated, we need to consider how the most popular of all English translations, Sylvester's Devine Weekes, responded to these strong precedents for including marginalia.

Given the prevalence of marginalia in the early editions described above, it might seem surprising that Sylvester's early translations contain so few. The margins are blank in The Triumph of Faith (1592), which includes translations of "Les peres" (II.iii.2) and the conclusion of "Le schisme" (II.iv.3), both of which were revised for Devine Weekes in 1605, and which Susan Snyder argues were probably translated from a 1591 Haultin edition that contained Goulart's marginalia. ${ }^{42}$ Nor do any marginalia appear in the six parts (II.i.1-4 and II.ii.1-2) published as The Second Weeke in 1598, the text of which survives largely intact in $1605 .{ }^{43}$ Marginalia are also absent from the translation of "Les colonies" Sylvester presented to King James in manuscript shortly after the accession, promising a complete translation soon. ${ }^{44}$ Because Sylvester explicitly intended the copy as a preview of a greater printed whole in his letter to James (5r), this manuscript indicates that marginalia were probably produced between 1603 and 1605 as Devine Weekes was being prepared for print.

This narrative supports Snyder's contentions that Sylvester's earlier translations indicate his lack of interest in marginalia, and that Humfrey Lownes was the driving force behind their inclusion in Devine Weekes. Lownes had successfully gained the right to publish the translation from Islip; perhaps, as Snyder suggests, because he had recently married his colleague Peter Short's widow. ${ }^{45}$ Within this period, Lownes printed a range of texts in different formats appropriate to each. John Dod's Plaine and Familiar Exposition (1606, STC 6954), for example, was printed on quarto sheets with scriptural cross-references in the margins intended to fulfill the book's stated aim to "tender the profit of the simplest readers" (A4r). Philemon Holland's translation of Suetonius's Historie of Twelve Caesars (1606, STC 23423) was printed in a folio edition and contains copious annotations that divide the work into discrete sections and furnish the reader with glosses and comments. A more modest publication like Michael Drayton's Moyses in a Map of his Miracles (1604, STC 7209) was a quarto edition with a more austere page layout and occasional marginal notes only (the first of which alludes, as it happens, to "Bartas" [A2r]). Lisle's published translations and

\footnotetext{
42. Snyder, Divine Weeks, 68. The Triumph of Faith, The Sacrifice of Isaac, The Ship-Wracke of Ionas. With a song of the victorie obtained by the French king, at Yvry, trans. Josuah Sylvester (London, 1592, STC 21672).

43. The Second Weeke or Childhood of the World, trans. Josuah Sylvester (London, 1598, STC 21661.5)

44. British Library, MS Royal 17 A 41.

45. Snyder, Divine Weeks, 20.
} 
Barret's proposed edition, of which Lownes was evidently aware, almost certainly made the intellectual and commercial arguments for marginalia in a complete print edition of the Semaines even more persuasive.

While Lownes may have had solid incentives to include marginalia, their presence was not necessarily contrary to the translator's wishes. Indeed, Sylvester's ardent desire for patronage, readily apparent from the extensive prefatory materials to Devine Weekes, suggests that he would have welcomed marginalia; they could have helped confirm Du Bartas as a laureate poet, a status emphasized in a woodcut portrait found in 1608 and subsequent editions (B1v). The translations printed in 1592 and 1598 were smaller publications in which finding aids and explanatory glosses were less important because of their length and familiar subject matter, such as the Fall and the Jonah story. A complete translation brought with it new opportunities for reading and using the poems and created more need for a set of analytical tools to lend the translation pedagogical value as well as prestige. The "Order of the Bookes or Tracts" with page references (1605 edition, B1r), argument stanzas, running headers, and "index of the hardest words" $(2 \mathrm{X} 2 \mathrm{r}-2 \mathrm{X} * 3 \mathrm{r})$ directly enabled such uses, and these features remain in subsequent editions, which from 1608 onward also contained separate title pages to each of the two Weeks and the multipart Days of the Second Week. As printed in its numerous quarto editions, Devine Weekes was not prepared only for a royal reader and those around him in court; the text joined numerous others in Lownes's output from this time in offering marginalia for fruitful navigation, clarification, and interpretative direction.

Marginalia supplied for a vernacular poem published in London in 1605 would have held similar contextual associations to those in Goulart's editions printed twenty years earlier in France. Annotations were prevalent in books printed in England at this time. William Slights has calculated that roughly 60 percent of new books printed in 1605 contained marginalia of some kind, 35 percent of which are heavily marginated (i.e., containing more than three notes per page) ${ }^{46}$ These books were literary, historical, legal, and, most frequently of all, theological. According to Slights, "in 1605 it was imperative to colonize the text along its borders... Those receiving the text had to be prepared, tutored, disabused of their prejudices and preconceptions, coerced into accepting the piece for what it was intended to be. The marginating procedure, then, was always more or less intrusive." And while Slights is surely correct that "a good way to make a book seem important and, hence, marketable was to accentuate its affiliation with older traditions of textual production," 
logical traditions mentioned above, the makers of Devine Weekes were only following existing trends in their decision to include marginalia. Other long poems and translations from the period contain printed marginalia, which could potentially be analyzed in similar ways: Barnaby Googe's translation of Marcus Stellatus Palingenius's Zodiacus Vitae (1576), which was used in Elizabethan schools; Michael Drayton's Poly-Olbion (1612); Phineas Fletcher's The Purple Island (1633); John Davies's Nosce Teipsum and Orchestra (1622); John Davies of Hereford's Microcosmos (1605); and George Sandys's translation of Ovid's Metamorphoses (1632). The use of marginalia in Fletcher's and in Davies of Hereford's poetry may be influenced by the Semaines and/or Devine Weekes, for both poets were known admirers of Du Bartas's work. ${ }^{49}$ John Harington's translation of Ariosto's Orlando Furioso (1591) is also worth mentioning as a nonscriptural work containing authorial annotations and other apparatus allowing readers to browse the book as a collection of separate stories. ${ }^{50}$ The inclusion of marginalia in Devine Weekes situated the poems within a wider English tradition of providing annotations for vernacular poetry, with related literary, pedagogical, and scriptural associations that encouraged various discontinuous reading practices.

The first edition of Devine Weekes, and Workes (1605, STC 21649) contains translations of all Goulart's marginalia into English. Sylvester probably translated and aligned them with the text, since both tasks required good knowledge of French. He continued to use a Chouët or Chouët-based edition that would have been annotated right through to the final section in "The Columnes" (II.ii.4, 2I1r-2K6r) ${ }^{51}$ Devine Weekes also contains original marginalia, and Snyder is probably right to maintain that Sylvester composed them, ${ }^{52}$ for they reliably appear at the beginning of the translator's interpolations (e.g., F7r, K8r). Slights observes that the notes in Devine Weekes serve to domesticate the poem for readers, but this function should be set alongside the clear continuity with Goulart's editions the marginalia established for English readers and the schoolroom practices with which they accorded. ${ }^{53}$ The annotations in Devine Weekes force the reader to make assessments about voice and tone. At the start of the First Day of the First

49. Phineas Fletcher, Purple Island (London, 1633, STC 11082), A2v; Davies of Hereford's laudatory verses are found in Devine Weekes, and Workes (London, 1608, STC 21650), B6r, 2N5v$7 \mathrm{r}$.

50. Gerard Kilroy, "Advertising the Reader: Sir John Harington's 'Directions in the Margent' [with Illustrations]," English Literary Renaissance 41 (2010): 64-110.

51. Evidence from Latin and Greek commendatory poems found within the 1605 Devine Weekes taken from French editions support Snyder's contention (Divine Weeks, 68-69) that Sylvester must have used the 1589 Chouët, 1591 Haultin, or another related edition containing Goulart's marginalia in 1605 as well as in the 1590s.

52. Snyder, Divine Weeks, 100, 103.

53. Slights, Managing Readers, 172-75. 
Week, Goulart's very first annotation gives a précis of the invocation: "The Poet imploreth the gracious assistance of the true God of Heauen, Earth, Ayre, and Sea, that hee may happily finish the Worke he takes in hand" (C1r). Sylvester supplies his own invocation shortly after (italicized, as all Sylvester's interpolations are), and has an accompanying annotation: "The Translator, knowing and acknowledging his owne insufficiency for so excellent a labour, craueth also the ayde of the All-sufficient God" (C1v). As the poem continues, the reader hears Goulart's voice spoken through Sylvester in marginalia that serve the functions already described, principally identifying topics such as "Commendations of the country life" (I7r) and "Difference between the Eclipses of the Sun, \& of the Moone" (L7r), giving scriptural cross-references (e.g., D6r), and noting similes (E1r). Printed marginalia occur approximately every fifteen lines in Sylvester's translation of La sepmaine, and there are rarely as many as fifty lines between two annotations. The marginalia are most prominent in the poem's more digressive sections and its lengthy catalogs. A hundred-line passage in the Fourth Day, for example, describes each of the twelve signs of the Zodiac in turn (I3r$4 \mathrm{v}$ ), and the notes divide the text into separate sections by naming the sign alluded to in the text and the associated month, for example: "Scorpio in mid-October" (K6r). A reader who wished to discover what Du Bartas has to say about, for instance, bees only had to look through the Fifth Day to find the marginal annotation "Of bees." Charles Butler may have done exactly so when researching The Feminine Monarchie; or, The Historie of Bees (1623); he quotes eleven lines from this section, noted in the margin as from "Du Bartas. Fift day" (D3v).

Devine Weekes as printed in 1605 was not yet a complete translation of the Semaines, and Lownes and Sylvester had to negotiate problems created by the final two Days of La seconde semaine omitted from the first printing. In particular, the Third and Fourth Days of La seconde semaine have a more complicated textual history and consequently far fewer annotations in French editions. Goulart composed marginalia as reading aids for these sections, but never produced a commentary for them. ${ }^{54}$ Chouët printed "La loi" (II. iii.3) in 1593 with Goulart's marginal annotations, but otherwise these sections were issued over an extended period and with little textual apparatus. "La vocation" (II.iii.1) and "Les captaines" (II.iii.4), for example, were not published in French until 1603 by Jacques Du Pin, and annotations were not provided until later still. ${ }^{55}$ After being reissued with an elaborate frontispiece in 1605 (STC 21649a), Devine Weekes was published with I Posthumus Bartas in 1606 (STC 21649a.5), which contained the untranslated sections from the Third Day of La seconde semaine, and with II Posthumus Bartas in 
1607 (STC 21665) to provide most of the remaining material from the Fourth Day. I Posthumus Bartas contains a few marginal annotations, some of which were translated from "La loi" but which are otherwise likely to have been composed by Sylvester. The first 110 lines of "The Vocation" in I Posthumus Bartas contain just four annotations, three that label similes and one marking a "Dedication to the Kings Maiestie" (2L*2), which in the poem refers to James before he acceded to the English throne: "Iames, richest Iem of Scots, and Scotland's Praise." II Posthumus Bartas contains none at all, and the publication also lacks the two final sections, which Snyder suggests is because Sylvester wanted his patron, Prince Henry, to receive the work without any delay. ${ }^{56}$

It was almost inevitable, then, that the sections new to the edition of 1608 (STC 21650), the first complete translation of the Semaines into English, would not have such detailed textual apparatus. The relative scarcity of marginalia is apparent in the first new section in the 1608 edition. The few annotations for "The Vocation" composed for I Posthumus Bartas are also replicated almost exactly in the later editions of 1611 (STC 21651) and 1613 (STC 21652) without improvement. ${ }^{57}$ In other sections that contained no Goulart commentary, there is a slow accumulation of marginalia in the 1608 and 1611 editions. "The Fathers" (II.iii.2) contains no marginalia at all in 1608 (2G5v-2H5r), but five notations of a simile (e.g., 2F6r) and one of an invocation (2F4r) are inserted by 1611 and retained in subsequent editions. 58 "The Captaines" contains extensive marginalia in both 1608 (2L3r2N5r) and 1611 (2I7r-2L8r) editions, identical to those in I Posthumus Bartas and offering little evidence that Goulart's marginalia were a source. Across the four parts of the Fourth Day of the Second Week, the 1608 edition contains just thirteen marginal annotations, twelve of them marked with asterisks, and only one offering a descriptive outline ("The wracke of Jonas," 3G5v). The 1611 editions retain these asterisked annotations, and in addition supply a functional outline. An annotation like "Dauids instructions to his Son Salomon" (2O5r) is followed by a series of qualities, such as being "Impartial in bestowing Preferments" (2O5v). This is more apparent in "The Magnificence" (II.iv.2, 2O4r-2Q7r) than "The Schism" (II.iv.3, 2Q7v-2S5v) or "The Decay" (II.iv.4, 2S6r-2V6v).

These additions suggest an attempt to provide marginalia for sections of Devine Weekes that would otherwise have had blank margins. As these new

56. Snyder, Divine Weeks, 100 .

57. The only difference is that the 1608 edition has an extra "Simile" alongside "But as a narrow and thin-planted Cops" (2E7r) that is dropped in 1613 (2D5r) and folio editions.

58. "The Fathers" translation (revised from 1592) was also printed, without any marginalia, in the 1605 edition: it is called "A Fragment of the Historie of Abraham" (i.e., of the Third Day, 2K8r-2L8v). 
annotations offer such little interpretation or explanation, they may have been supplied expressly to improve the printed layout of the book. While there may be little interpretative value in a lone annotation like "Simile," the note brought the commentator's voice back into the poem; moreover, it was easy to spot and label, since comparisons are almost always signaled by "as" or "like" in the poems. Very few marginalia are added to the 1613 edition, a lack which Snyder attributes to the death of Prince Henry. ${ }^{59}$ The text and annotations in the folio edition of 1621 (STC 21653) are substantially the same and are retained in 1633 (STC 21654) and 1641 (Wing D2405) ${ }^{60}$ In both of these later editions each page is divided into two columns, which leaves much less space for marginal glosses.

From this summary account of marginalia in editions of Devine Weekes, we see that they persisted as a relevant, active feature of the work's material existence. Goulart had hinted in his correspondence that his annotations were composed to make his edition of the Semaines more appealing to readers, and the same may well go for the marginalia in the seventeenth-century English editions. ${ }^{61}$ They provide some insight into how printer and probably translator expected the book to be used, especially in enabling nonserial, extractive reading for educational profit. The printed text of the poems may have looked bare to some readers without them. Within a publishing environment in which printed marginalia were frequently found in similar books by Lownes and others within the same period, it seems likelier than not that for many readers the marginalia were functional rather than purely decorative. To prove this hypothesis, however, we need to move from production to consumption and assess evidence about how individual readers actually used their copies of Devine Weekes.

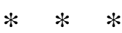

The Northamptonshire diarist Elizabeth Isham reported in her "Booke of Rememberance" (ca. 1639) that she was distressed by "the reading of Dubertus in a place reasoning with an Athest as I take it for I doe not well remember the words, it was now the second time lit was/ I read the booke I liked it so well. neither was I troubled with reading the place afore. which doth $\backslash$ [ever]/ make me take the fault or weaknes to be of my selfe /rather\then any hurt of the Booke (which since I have found some places to maintaine the truth of the diety). ${ }^{.62}$ Isham records that she has read the Semaines more

59. Snyder, Divine Weeks, 104

60. Ibid., 106.

61. Jones, Simon Goulart, 30, 372.

62. Elizabeth Isham, "Booke of Rememberance," 31r, http://www2.warwick.ac.uk/fac/arts /ren/projects/isham. 
than once, though not necessarily all of the Days nor in sequence. If she was reading either Sylvester's translation or an annotated French edition, she may have been alerted to passages on "atheism" in the First Day (1605, C2r) or "The Arke" (2D4r), which have printed marginalia noting that Du Bartas is "confuting" the atheists. Though marginalia did not help Isham locate a passage which she was not looking for, they may have helped her to apprehend its topic more rapidly. Even if she only lingered on this passage while reading through a longer section, Isham nonetheless paused at this point and compared it with other "places" (a word semantically related to "topos" and "topic"), probably from different sections in the work. Isham appears to have been a casual reader of the Semaines who approached the book for private meditation but was nonetheless drawn to nonsequential reading.

Her example is helpful for showing that marginalia did not instigate or dictate selective or extractive reading of the Semaines but they could complement such practices. Among the corpus of surviving evidence Isham's case is unusual. She apparently reads for pleasure ("I liked it so well"), reads the Semaines more than once, and listens to the text rather than imposing an interpretative framework on it. "Read" is the correct verb to use here, especially as Isham uses the word herself. But in other cases it feels less appropriate; as William Sherman notes, "reading" tends to imply "privacy, linearity and cleanliness" whereas early modern book use encompasses a broader variety of settings and agendas that were often public and goal oriented. ${ }^{63}$ Most of the available evidence about early modern book use in general, and the Semaines in particular, involves purposive writers who were either holding pens in their hands as they read or were searching for reusable quotations to extract.

Recent research into the history of reading has stressed the diversity of early modern reading practices; readers appropriated texts for their own ends-influenced but no longer bound to prescriptive humanist methods. ${ }^{64}$ Stephen B. Dobranski argues that textual features like printed marginalia

63. William Sherman, Used Books: Marking Readers in Renaissance England (Philadelphia: University of Pennsylvania Press, 2008), xiv; Lisa Jardine and Anthony Grafton, "Studied for Action': How Gabriel Harvey Read His Livy," Past and Present, no. 129 (1990): 30-78, but also such studies as Alastair Fowler, Renaissance Realism: Narrative Images in Literature and Art (Oxford University Press, 2003); and Sasha Roberts, Reading Shakespeare's Poems in Early Modern England (Basingstoke: Palgrave Macmillan, 2003), 113-29.

64. Important studies in early modern reading practices include Heidi Brayman Hackel, Reading Material in Early Modern England: Print, Gender, and Literacy (Cambridge University Press, 2005); Kevin Sharpe and Stephen N. Zwicker, eds., Reading, Society, and Politics in Early Modern England (Cambridge University Press, 2003); Peter Mack, "Renaissance Habits of Reading," in Renaissance Essays for Kitty Scoular Datta, ed. Sukanta Chaudhuri (Oxford University Press, 1995), 1-25; and Eugene R. Kintgen, "Reconstructing Elizabethan Reading," Studies in English Literature 30 (1990): 1-18. 
were sites of interpretative tussles between reader and author, as "authors responded to the potential lack of control that came with print publication by forecasting interpretative strategies in printed marginal notations and introductory epistles." ${ }^{\prime 65}$ Marginalia could draw attention to particular words, ideas, and structures, but could not compel readers to interpret the poems in a single way, as Isham's different reaction on her second reading confirms. Printed annotations cannot tell us how individuals used the Semaines since, as the brief comparison between manuscript and print marginalia above showed, the marginalia are likely to have been created as a response to prevalent habits of reading and note taking rather than to have initiated them. What we can see from contemporary readers, however, is how the culture of literary excerption and nonserial reading affected how readers used these books as well as how printers produced them.

The compatibility of Devine Weekes with practices of commonplacing is most vividly shown in Robert Allott's printed commonplace book, Englands Parnassus (1600). Allott extracted more than eighty quotations from Sylvester's Second Weeke even though he did not have access to later annotated editions and is unlikely to have consulted a French edition (though two unattributed couplets taken from "The Colonies" [II.ii.3] show that he did have access to Lisle's translation).$^{66}$ Allott's quotations are largely localized to sections with clear structures where it is easy to match extracts with headings in Englands Parnassus: for example, he takes five consecutive quotations from the same page at the end of the 1592 edition (sig. C3r) in a section where the topic of each paragraph is given in the first line ("Repentance," "Praier," and "Fasting") and matches Allott's headings. Strikingly, Allott's headings often anticipate marginalia that are absent from the edition he was using. A passage quoted under "Of the Hebrew tongue," for instance, would gain the marginal annotation "Praise of the Hebrew Tongue" in Devine Weekes (1605). Similarly, the headings "Of the Rainebow," "Of a drunken man," "Of Eden," and "Of Scaliger" are all found, almost identically, in Englands Parnassus and later in Sylvester's margins. ${ }^{67}$ These coincidences result from the compiler's tendency to select quotations that contain a topic word in the first line of a verse paragraph, for instance: "Nepenthe, enemy to sadness" (B1v [1598]; "Nepenthe," 2K4r, no. 2317) and "Th'ayres

65. Stephen B. Dobranski, "Reading Strategies," in Oxford History of Popular Print Culture, vol. 1, Cheap Print in Britain and Ireland to 1660, ed. Joad Raymond (Oxford University Press, 2011), 105.

66. Robert Allott, England's Parnassus, ed. Charles Crawford (1600; Oxford: Clarendon, 1913), 382. For clarity, Crawford's numbering of quotations is indicated with the abbreviation "no." before the quotation number. Cummings, "Tudor Translation," 191, 196.

67. 2I8v, no. 2297, cf. Sylvester's translations at F2r-v (1598) and 2F2r (1605); 2A1r, no. 1938, cf. K5v (1598) and 2D7r (1605); Z8v, no. 1934, cf. K6v (1598) and 2D8r (1605); Z8r, no. 1932, cf. Alr (1598) and T5r (1605); 2I8r, no. 2295, cf. Flv (1598) and 2E8v (1605). 
daughter Eccho" (A7r [1598]; "Of Eccho," 2K4r, no. 2318). Although there is no causal link either way between Allott's headings and Sylvester's marginalia, the correlation indicates that printed marginalia matched recognizable conceptual structures in the text of the kind that Miernowski describes in detail. Marginalia would have benefited Allott had they been available and were later used in commonplacing techniques learnt from humanist pedagogical practices.

Marginalia offered practical assistance for prose authors like Helkiah Crooke who wanted to find usable quotations. In his anatomical treatise Mikrokosmographia (London, 1615), Crooke borrows a six-line simile comparing mutability to a strumpet for inclusion in a section "of the Necessitie of the parts of Generation" (S4r; Sylvester, I.ii.227-32). The printed marginalia in Devine Weekes may have helped Crooke extract the desired passage. The facing page (E3v) contains a prominent annotation observing that the section's topic is the "continuall Change of the World in the matter and form thereof," and the beginning of the verse paragraph from which the simile is taken is marked "Sundry Similes to that purpose" (E4r). It is impossible to prove that Crooke's eyes alighted on particular marginalia immediately before borrowing from Sylvester, but the strong correlation is worth observing because it encourages us to think that annotations help us appreciate how a reader and writer like Crooke used the poems.

Similarly, George Hakewill's eighteen quotations from Sylvester's translation in An Apologie of the Power and Prouidence of God in the Gouernment of the World (Oxford, 1627) hint that he also looked at the margins to locate passages relevant to his argument. ${ }^{68}$ Hakewill's use of Du Bartas corroborated Hakewill's defense of modern learning, and again printed marginalia supported the claims for intellectual legitimacy. An extract reprinted on Hakewill's L4r, for example, is marked in Devine Weekes with a note, "The first creature, extracted from the Chaos, was Light" (1605, D1r). This effectively summarizes the argument Hakewill wants to make, as does a label to a long quotation on N1v-2r, "of the force and influence of the celestiall bodies upon the terrestriall” (L1r). Hakewill probably used Sylvester's printed marginalia to identify relevant sections of the argument; he usually quotes from the start of verse paragraphs, and edits quotations to fit their new context. Hakewill quotes lines marked in Devine Weekes (1611 edition) with a marginal annotation, "The I. creature extracted from the Chaos, was Light" (C7v, I.i.479-82), that relates closely to his argument: "From whence should the voice of God in holy Scripture begin, but from the light?" (L4r). ${ }^{69}$ And it

68. Quotations are taken from the 1627 edition (STC 12611) rather than the expanded 1635 edition (STC 12613), and are given parenthetically.

69. See bk. 3 for further examples of Hakewill seeming to use Sylvester's marginalia, e.g., 1.6.885-96, 897-906 (quoted on 2I4r). 
was not just prose writers who appear to have used printed marginalia for assistance in writing their works. Edward Browne, author of a poem sequence containing lengthy verbatim quotations from Devine Weekes, assembles his centos in a way that is sensitive to paragraph divisions and printed marginalia. In his poem "Sunday," Browne uses sections corresponding to marginal references, "Genes. 1.2" (I.i.269, C5v [Devine Weekes, 1605]) and "Gen. 1.3" (I.i.521, D2r), and in "Monday" to "the 1. Cha. of Gen. ver. 6,7,8" (I.ii.58, E1r) and "Gen. 1.7" (I.ii.1148, G3v) ${ }^{70}$

Manuscript annotations to Devine Weekes often complemented, paralleled, or expanded upon printed apparatus, especially in aiding navigation to specific sections. ${ }^{71}$ A copy of La seconde semaine owned by James Bisse (who died in 1607) contains indexes of topics and rhetorical figures, while the copy of Devine Weekes (1608 edition) that Thomas Edwards obtained in 1610 contains handwritten cross-references to other texts, underlined passages, and similes marked in the margin. ${ }^{72}$ In both cases we find readers supplementing the existing apparatus. More informal reading notes are found in Lawrence Omer's copy of the 1608 edition; this contains notes, underlinings, and one-word summaries such as "Creation" (1608, C5r), "World" (C6r), and "Doomsday" (C6v) ${ }^{73}$ Relatively few quotations from Devine Weekes appear in manuscript commonplace books from this period, however. A rare exception is a manuscript miscellany from the second half of the seventeenth century that quotes freely from across Sylvester's translations and retains marginal glosses as topic headings: "Maiz is Indian wheat" and "of the growing of Oates" (fol. 8v) are retained from Devine Weekes (1621, H2v), as is "A pleasant discription of loves fruitfull grove" (fol. 28r; Devine Weekes, 2R6r) ${ }^{74}$ As Allott's example from half a century earlier indicated, marginalia were sometimes interchangeable with headings in commonplace books. The relative paucity of other examples from manu-

70. Browne, A Description of an Annual World, and Sacred Poems (London, 1641, Wing B5102, B5102A, B5106).

71. On interpreting manuscript markings, see H. J. Jackson, "Editing and Auditing Marginalia," in Modiano, Searle, and Shillingsburg, Voice, Text, Hypertext, 72-80; for a recent case study, see Fred Schurink, "Like a Hand in the Margine of a Booke': William Blount's Marginalia and the Politics of Sidney's Arcadia," Review of English Studies 59 (2008): 1-24; and on relationships between annotation and text, see Stephen Barney, ed., Annotation and Its Texts (Oxford University Press, 1991).

72. Bisse's copy of La seconde semaine (Paris, 1584) is held by the British Library (839.h.27); Edwards's copy of Devine Weekes and Workes (1608 edition) is held by the Codrington Library, All Souls College, University of Oxford (rr.2.20).

73. Copy held in the library of Queen's College, University of Oxford (classmark: UUb.4502).

74. Leeds University Library, Brotherton Collection, Lt 91. Images and Sebastiaan Verweij's detailed description of the book are available on Scriptorium, http://scriptorium.english .cam.ac.uk. 
script miscellanies and commonplace books may indicate that the poems were often looked on as printed commonplace books in themselves that did not require further textual intervention or exception. Certainly the marginalia in Devine Weekes attest to the presence of humanist practices of poetic analysis, textual excerption, and information storage and retrieval in habits of reading vernacular poems like the Semaines. Translators, printers, and publishers produced editions to encourage such practices.

Devine Weekes's marginalia bear out the truth in Neil Rhodes's diagnosis of "the status anxieties that frequently attended English Renaissance translations and which were then transferred to their accompanying paratexts on publication." ${ }^{" 75}$ Marginalia may have served as a palliative to worries that an English translation of the Semaines would be incomplete, insufficient, and indecorous without due recognition of its learning, but they also played a positive role in creating new opportunities for the book's readers and users. The printed marginalia in Devine Weekes help us to situate the poems among broader contemporary practices in book production and poetry appreciation. Their presence in all editions of Devine Weekes displayed the work's continuity with active, learned reading methods and also facilitated these methods. A key way to relieve any status anxiety regarding the poems would have been to draw attention to their practical function. Devine Weekes indeed encouraged early readers to consult the Semaines for their rhetoric, learning, and memorable exempla.

This study of printed marginalia in Devine Weekes has suggested new ways to approach poems which some still regard as "possibly unreadable" and eminently ignorable. ${ }^{76}$ Specifically, it has offered a possible corrective to readings that approach the Semaines as narrative poems designed to be read in sequence, and, unsurprisingly, find them repetitive and derivative. Marginalia draw attention to the unique architectonics of the Semaines and make their descriptions and digressions less confusing. None of this leads us to assume outright that the Semaines were only read discontinuously in this period, but we should be alert and sympathetic to earlier reading practices that expand our sense of the poem's varied appeal. ${ }^{77}$ Devine Weekes provides

75. Neil Rhodes, "Status Anxiety and English Renaissance Translation," in Smith and Wilson, Renaissance Paratexts, 120.

76. Jonathan Sawday, The Body Emblazoned: Dissection and the Human Body in Renaissance Culture (London: Routledge, 1995), 89.

77. See, e.g., William Slights, "Back to the Future-Littorally: Annotating the Historical Page," in The Future of the Page, ed. Peter Stoicheff and Andrew Taylor (University of Toronto Press, 2004), 71-84. 
valuable evidence about the function of printed marginalia in vernacular poetry, and about the legacy of humanist practices in popular vernacular literature. It is, of course, possible to read Devine Weekes fruitfully in critical editions without marginalia. But to neglect them is to disengage from the enriching cultural traditions in which the poems were first read and admired. 